\title{
MUSEUM EDUCATIONAL ACTIVITIES IN THE CASE OF ARCHAEOLOGY IN PTUJ
}

\begin{abstract}
In this paper we discuss about some of the most successful activities and educational programs of museum in Ptuj in Slovenia. In Ptuj-Ormož regional museum we have started with innovatory program of representing an archaeological material to the youngest population. Along with the exhibition Prvošolčki v ptujskem muzeju (First graders in Ptuj museum) we have, with various activities, approached them the historical development of the town Ptuj.

With such schemed work we also continued through other themes, we acquainted all generations about everyday life in Roman Poetovio. The upgrade of this work is cooperation with surrounding societies, among which is the most active with Society of Women and Girls of Hajdina Commune, with schools and with Ptuj Spa.
\end{abstract}

Keywords: Slovenia, Ptuj-Ormož Regional Museum, pedagogical and andragogical education, archaeology, cultural heritage.

On the present-day Slovenian territory the Ptuj museum is after the Ljubljana (1821) and the Celje museum (1882) the third oldest institution of that kind, and it is the central museum in the Ptuj-Ormož area. It takes care of the preservation of the moveable cultural heritage in that area from the oldest time periods to the present age (Vomer Gojkovič and Kolar 1993, 9-20). We present the cultural heritage for visitors of all ages in form of museum collections, occasional exhibitions and diverse activities of popularization (publications, lectures, workshops etc.). We pay a special attention to young visitors. Through various activities and educational programs we get them acquainted with the life in the past by using museum collections and objects. The museum is an educational institution where visitors, on the basis of studying the museum material, get an insight into the cultur- al and historical development of this region (Kolar 2003: 12). It is also a place where lovers of the cultural heritage get together in order to present the customs and habits of the Ptuj-Ormož area to the domestic and foreign public (Fig. 1).

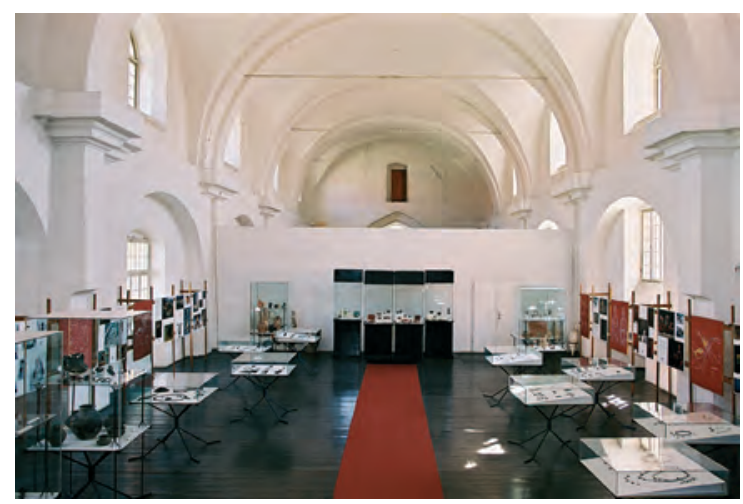

Fig. 1 Former Collection of small archaeological material in Ptuj - Ormož Regional Museum (1967-2011) 


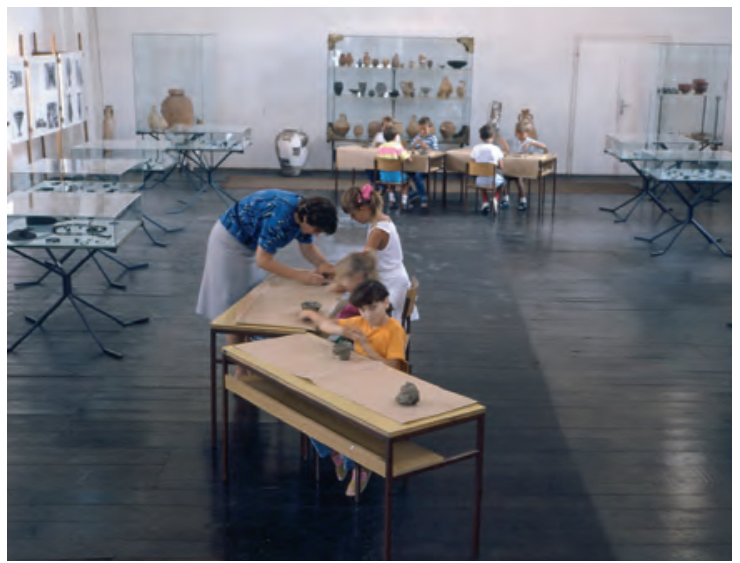

Fig. 2 First-graders at modelling of pottery from clay

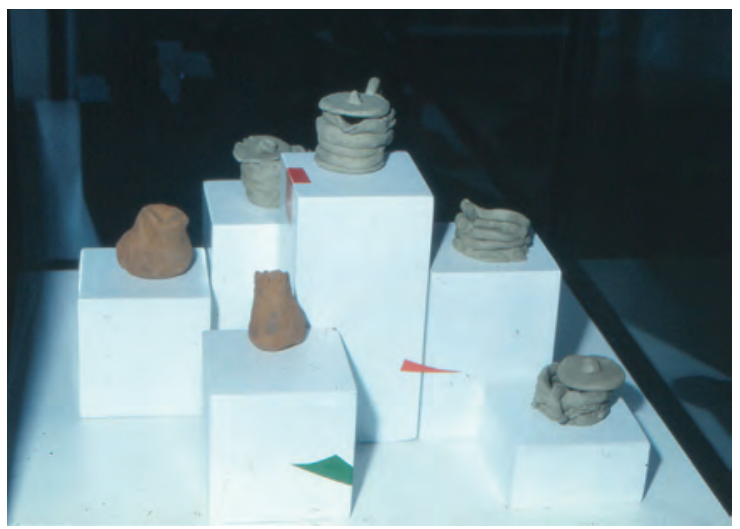

Fig. 3 Pottery, which was made by first graders

Thanks to the exhibition Prvošolčki v ptujskem muzeju (First-Graders in the Ptuj Museum) we started with an innovative program presenting archaeological material to the youngest population. With the exhibition First-Graders in the Ptuj Museum we made the children acquainted with the cultural heritage in the Ptuj-Ormož area, and at the same time, we informed them about the universal development of the mankind from the oldest time periods to the present days. The exhibition is the result of a co-operation with the first-graders visiting the Olga Meglič Elementary School in Ptuj who, in the school year 1989/90, took a close look at the collection of small archaeological findings (Fig. 2). After the children had been acquainted with the pottery production process, they shaped different objects made of clay. They replicated prehistoric and Roman pottery products. Some objects were air dried and some of them were burnt (Fig. 3).

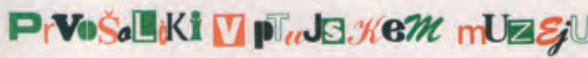

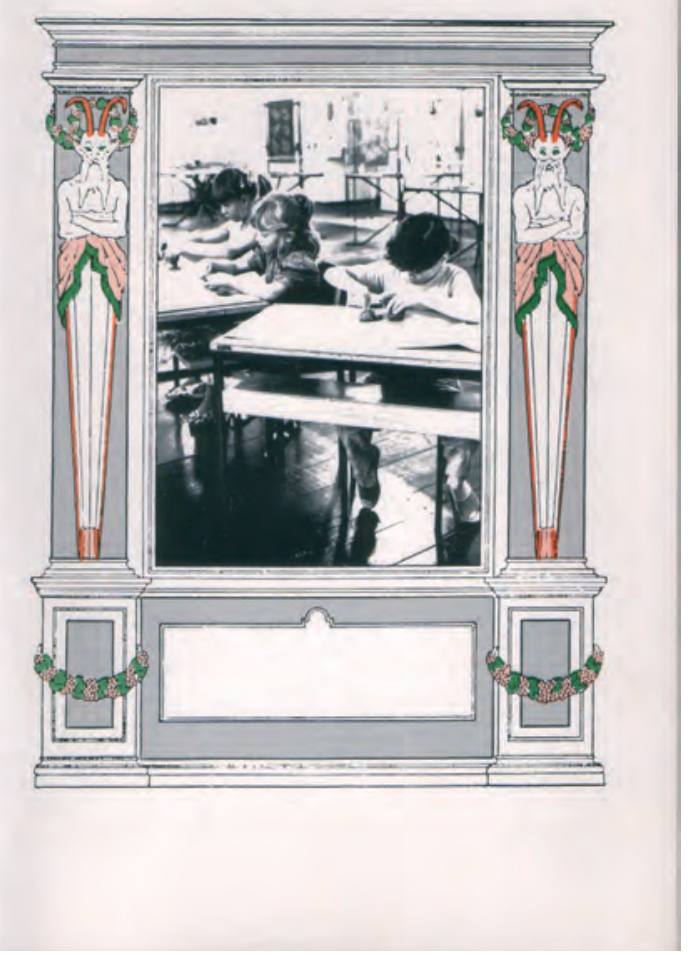

Fig. 4 Title page of publication The first graders in Ptuj Museum

The children, under the leadership of museum experts, then put their products into vitrines. The exhibition consisted of six vitrines in which 42 objects were exhibited. The ceramic production was accompanied by eight panels on which the ceramic production process at different time periods was explained by text and pictures. The exhibition poster showed the first-graders at work. The invitation to the exhibition and the catalogue front page were designed in the same manner (Fig. 4).

The text in the catalogue (Kolar and Vomer Gojkovič, 1990. Kolar and Vomer Gojkovič 1991, 66) is meant as learning material presenting the manufacture of pottery products from prehistory to Early Middle Ages; the text is complemented by photos and drawings. In the first part of the catalogue there is an illustrated chronological table showing the development of pottery fol- 


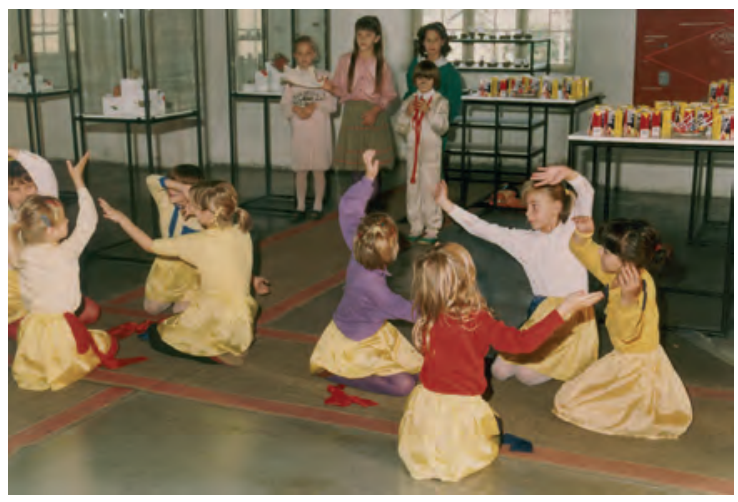

Fig. 5 Children have prepared cultural program at the opening of the exhibition The first graders in Ptuj Museum

lowed by a description of how pottery was being made. In the second part of the catalogue the visitor gets acquainted with the activities which the children performed during a lesson dealing with the collection of small archaeological findings with emphasis on ceramic. The catalogue ends with the list of children who participated in manufacturing the exhibited objects, and with the list of basic Slovenian literature about archaeological ceramic. On the occasion of the exhibition a video-film had also been shot, it was shown at the opening when the children also prepared a short program (Fig. 5).

During the course of the exhibition we prepared that kind of lessons also for the pupils visiting other schools. After they had heard a short explanation about the development of ceramic in various archaeological time periods and they had seen the video-film, the pupils shaped similar objects made of clay which were afterward put in a vitrine. More than 1300 pupils from various elementary and secondary schools attended those Art

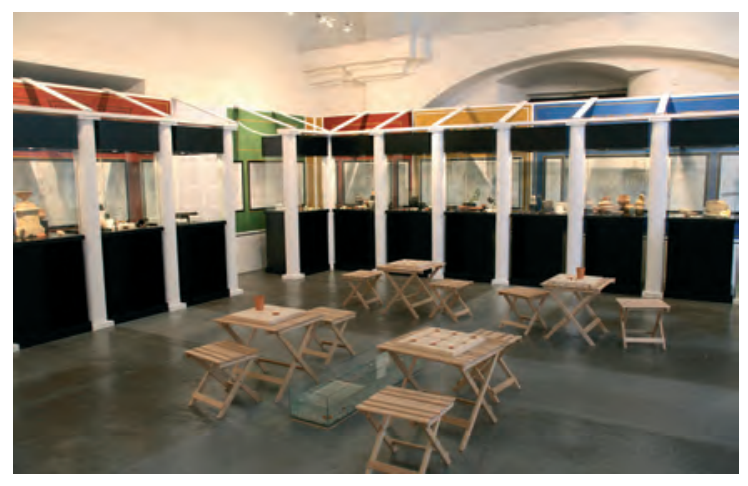

Fig. 6 The exhibition Roman Everyday Life in Poetovio

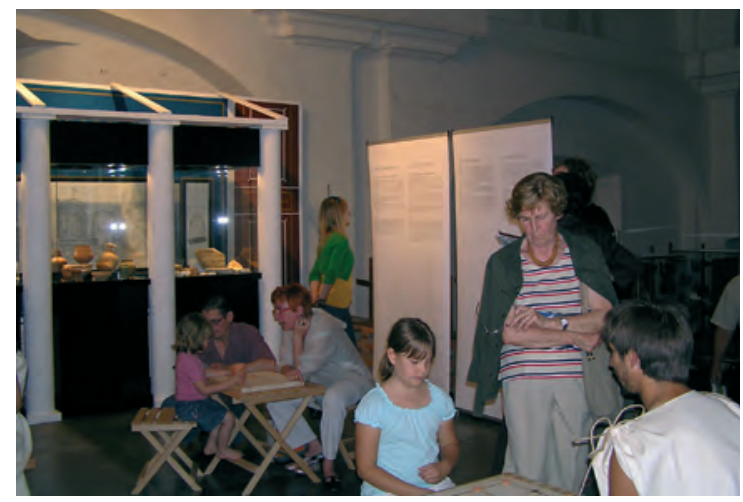

Fig. 7 Visitors playing the games, which were included in the exhibition Roman Everyday Life in Poetovio

lessons. After the exhibition had been closed the interest in such new active educational approach went on, therefore, we informed, with the help of the video film, the teachers of elementary and secondary schools in the northeast Slovenian area about our activities. We were the first museum in Slovenia that started with the pupils' active approach in Art lessons and with organizing museum educational workshops.

In the following years we continued the project First-Graders in the Ptuj Museum with various pedagogical and andragogical workshops that were linked with the archaeological collection or with occasional archaeological exhibitions (Pintarič 2010, 16-21. Stergar 2010, 220). A higher stage of that sort of activity was the cooperation with surrounding societies; the Society of Women and Girls of the Hajdina Commune belonged to the most active ones, furthermore with schools and the Ptuj Spa (Amber Expedition 2010-2011). By organizing thematically-oriented workshops (e.g. jewellery, clothing, ceramic) we

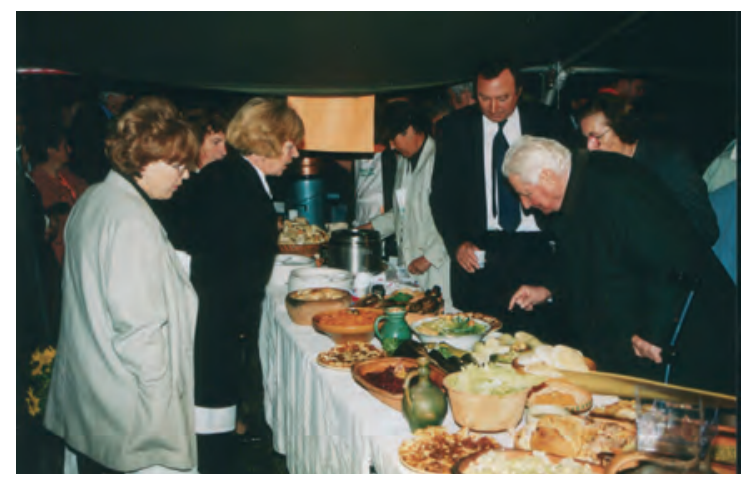

Fig. 8 Offer of Roman foods at the International Scientific Symposium Ptuj in the Roman Empire, Mithraism and its Era 


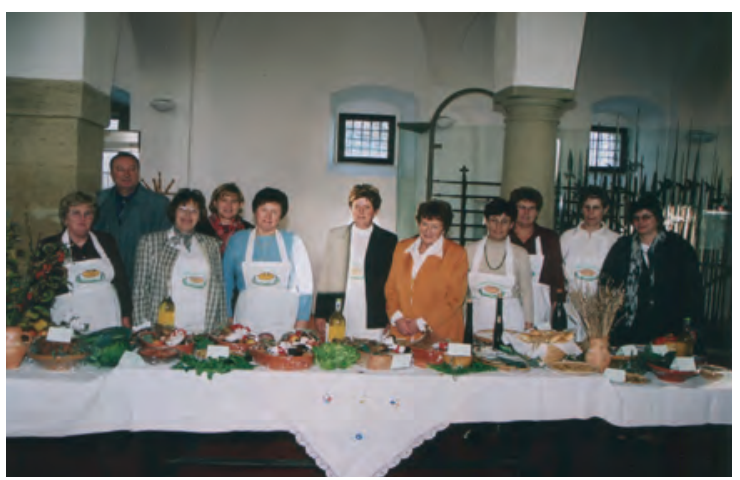

Fig. 9 The Society of Women and Girls of the Hajdina Commune in palatium of Ptuj Castle

acquainted people of all generations with the everyday life in the Roman Poetovio. On occasion of the exhibition Roman Everyday Life in Poetovio (Vomer Gojkovič and Žižek 2008: 10-11, 69-72), we prepared small tables meant for board games (Fig. 6). The visitors could imagine themselves as residents of Poetovio and play games which have already been known by ancient Romans (Fig. 7). In this way we tried to present the pulse of the town and its surroundings in the Roman Era and to bring the past closer to all age groups, among them there were also groups of people with special needs.

The museum is also a place where lovers of cultural heritage meet and socialize with each other in order to present customs and habits of the Ptuj-Ormož area to the domestic and foreign public. Some societies actively cooperate with the Ptuj Museum. Here, the Society of Women and Girls of the Hajdina Commune must be mentioned, because it participates in the preparation for numerous museum events and, thus, take cares of the preservation of old habits. The Society of Women and Girls of the Hajdina Commune has been

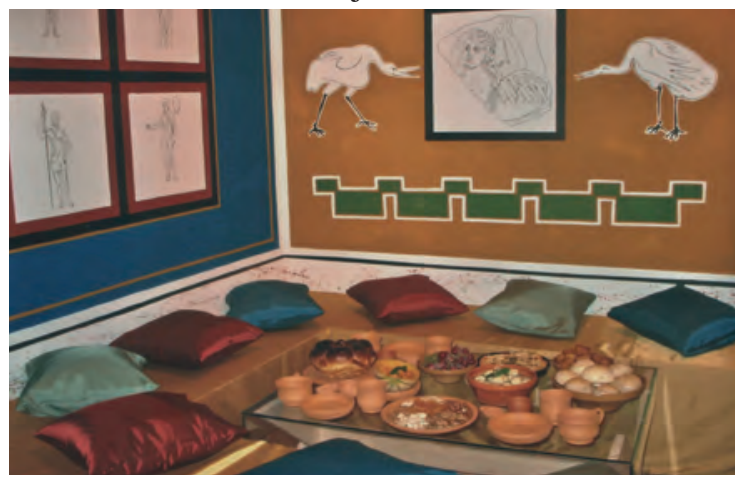

Fig. 11 Triclinium with Roman food, prepared by the Society of Women and Girls of the Hajdina Commune

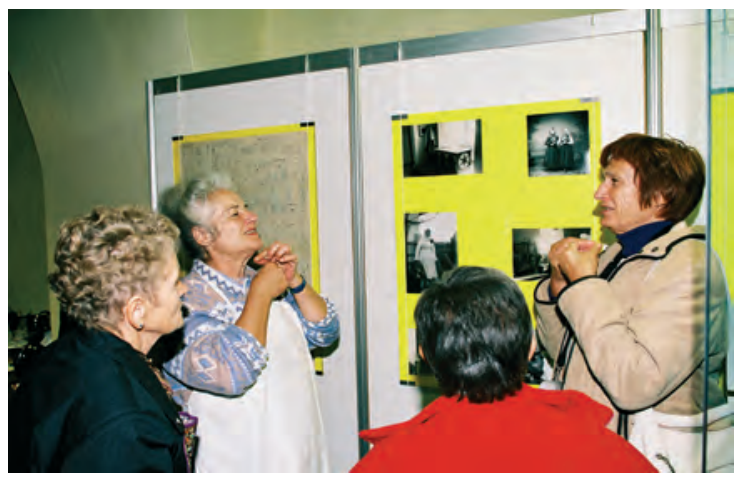

Fig. 10 Enthusiasm of visitors of the exhibition Who Made Little Vid a Shirt

cooperating with the museum since 1999 (Utrinki 2009), when the society members, during the international conference Ptuj in the Roman Empire, Mithraism and its Era (Vomer Gojkovič and Kolar 2000, 83-85), gave their contribution to this scientific meeting by preparing a warm reception for the conference participants in Hajdina and by serving them ancient Roman food (Fig. 8). They also took part in many other museum events (Fig. 9). So e.g. at the exhibition Cheers! Drinking Vessels from Slovenian Museums (Kolar and Vomer Gojkovič 2006) that was also shown in Wine Museum in Buttrio, Italy (Perko et al. 2007a, Perko et al. 2007b). At the exhibitions Who Made Little Vid a Shirt (Vomer Gojkovič and Kolar 2007.) (Fig. 10) and Roman Everyday Life in Poetovio (Vomer Gojkovič and Žižek 2008, 127) they exhibited their own products (Fig. 11), and at the opening of the exhibition they sang old folk songs (Fig. 12) and served traditional food. The Slovenian Archaeological Society honoured in 2010 their efforts for preserving the local traditions and the cultural heritage in its original environment with a merit certificate (Nagrade 2010: 161); in 2011 the Slo-

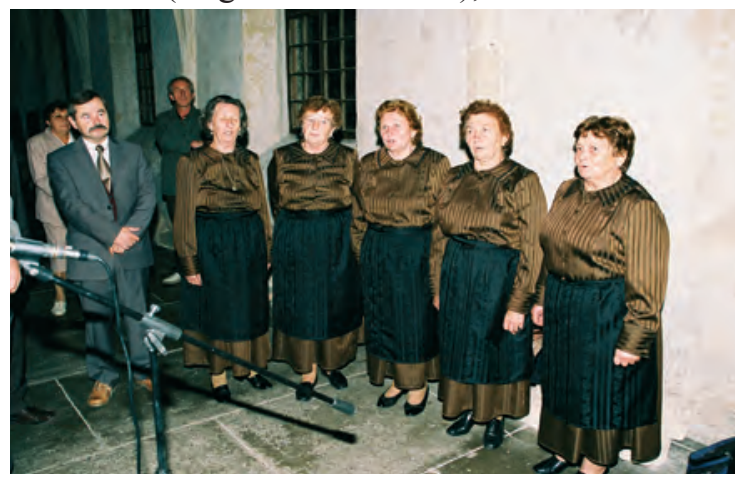

Fig. 12 Performance by folk singers at the opening of one of the exhibitions 


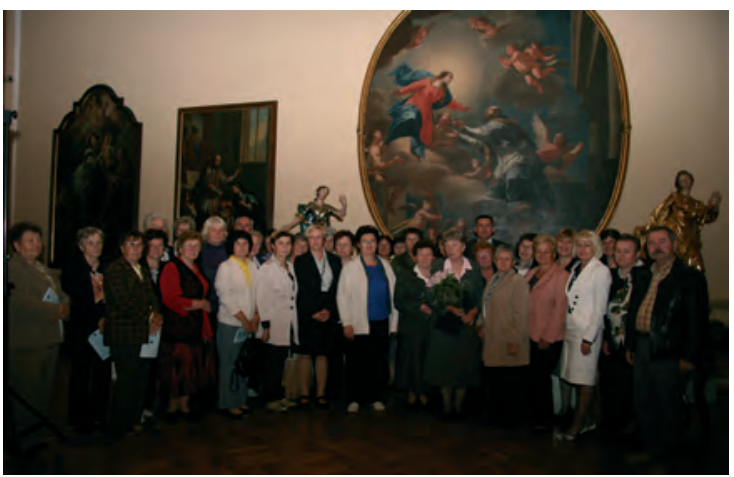

Fig. 13 Granting Valvasor honourable recognition granted by the Slovenian Museum Society awarded the Society of Women and Girls of the Hajdina Commune in 2011

venian Museum Society rewarded them with the Honorary Valvasor Prize for the cooperation with the Ptuj Museum (Valvasorjeva 2011: 15), (Fig. 13). The Society of Women and Girls of the Hajdina Commune takes part in presenting the Roman cultural heritage not only together with the museum, but also with other societies and institutions. Thus, this 2012 they again appeared dressed as Roman women (Fig. 14) at the fifth Roman Games organized by the Society 69, Society for Roman History and Culture Ptuj. In the middle of June 2012 they accepted the invitation of the Varaždin Spa and appeared as Roman women presenting Roman food at the traditional Aquafest.

The Hajdina Commune, the Hajdina Tourism Society, the town Varaždinske Toplice (Croatia) and the Homeland Museum of Varaždinske Toplice prepare a cross-border joint project dealing with the Roman Era heritage. The project title is Archaeological Parks in the Area of Ager

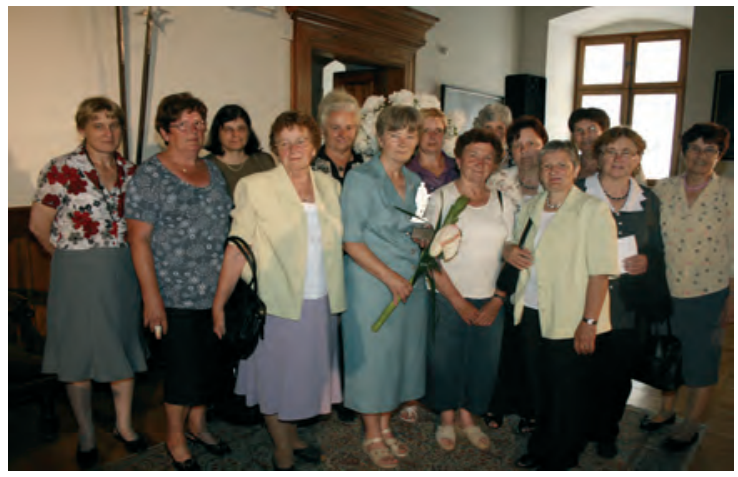

Fig. 15 The Society of Women and Girls of the Hajdina Commune at the granting document of thanks of the Slovenian Archaeological Society in 2010 in Celje

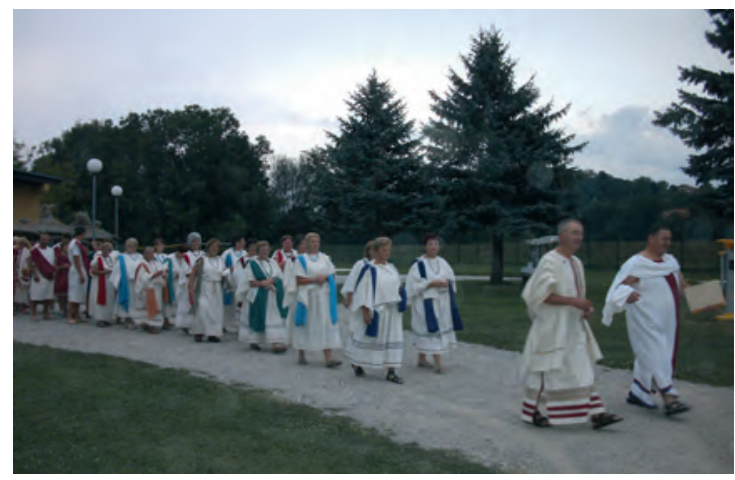

Fig. 14 The Society of Women and Girls of the Hajdina Commune as Romans at the 5th Roman games in the Ptuj Spa 2012

Poetovio - Vicus Fortunae and Ager of Aquae Isasae. The objective of the proposed project is to speed up the cross-border cooperation in the area of the Roman Era heritage. The project will contribute to the improvement of the common identity and the recognisability of the area, to knowledge extension about the common cultural heritage, to the preservation of the cultural heritage and to the increase of tourism on the basis of the Slovenian-Croat cooperation in the field of Roman provincial archaeology.

In connection with the future Archaeological Park Vicus Fortunae, we prepare various educational workshops which include knowledge about the history of the town, acquaintance with different forms of jewellery and ceramic products, their techniques and the cooking skills of the ancient Roman cuisine.

We mentioned only some projects performed at our museum and in cooperation with other institutions. By implementing pedagogical- andragogical education dealing with cultural heritage we achieved some success which can be seen by the fact that we received several national rewards (Fig. 15).

\section{BIBLIOGRAPHY}

\section{Amber Expedition 2010-2011}

European Cultural Route, project Culture 20072013: Kalisz.

Kolar, N. 2003

Pokrajinski muzej Ptuj med letoma 1893 - 2003, 
Zbornik Pokrajinskega muzeja Ptuj 1, Ptuj: Pokrajinski muzej: 9-12.

Kolar, N. and Vomer Gojkovič, M. 1990 Prvošolčki v ptujskem muzeju. Otroški pogled na keramiko: Ptuj Pokrajinski muzej Ptuj.

Kolar, N. and Vomer Gojkovič, M. 1991 Poročilo o razstavi Prvošolčki v ptujskem muzeju, Argo XXXI-XXXII: 66.

Kolar, N. and Vomer Gojkovič, M. 2006

Kol'kor kapljic, tol'ko let, Muzejski odsevi: Ptuj: Pokrajinski muzej Ptuj.

Nagrade Slovenskega arheološkega društva za leto 2010

Arheo 27/2010, Slovensko arheološko društvo: 161.

Perko. V. et al. 2007a

Živeli, Pivsko posodje iz slovenskih muzejev skozi čas, Buttrio, Kranj: Gorenjski muzej.

Perko. V. et al. 2007b

Salute! Il vasellame da bere dalle collezioni dei musei sloveni, 75. Fiera Regionale dei Vini di Buttrio.

\section{Pintarič, R. 2010}

Na muzejskem vikendu je lepo. Zbornik Pokrajinskega muzeja Ptuj - Ormož 2, Ptuj: Pokrajinski muzej Ptuj - Ormož: 16-25.

\section{Stergar, M. 2010}

S svinčnikom skozi muzej. Zbornik Pokrajinskega muzeja Ptuj - Ormož 2, Ptuj: Pokrajinski muzej Ptuj - Ormož: 210-222.

Utrinki, ob desetletnici Društva žena in deklet občine Hajdina 2009

Društvo žena in deklet občine Hajdina, ed. M. Vomer Gojkovič: Hajdina.

Valvasorjeva nagrada in priznanja za leto 2010

Slovensko muzejsko društvo, Ljubljana, Celje.
Vomer Gojkovič, M. and Kolar, N. 1993

ArchaeologiaPoetovionensis, Stara in nova arheološka spoznanja, Ptuj: Pokrajinski muzej Ptuj.

Vomer Gojkovič, M. and Kolar, N. 2000

Mednarodni znanstveni sestanek »Ptuj v rimskem cesarstvu, Mitraizem in njegova doba«, Arheo 20, Ljubljana: 83-85.

Vomer Gojkovič, M. and Kolar, N. 2007

Kdo je napravil Vidku srajčico, Muzejski odsevi, Ptuj: Pokrajinski muzej Ptuj.

Vomer Gojkovič, M. and Žižek, I. 2008

Rimski vsakdan $v$ Petovioni / Roman Everyday Life in Poetovio, Ptuj: Pokrajinski muzej Ptuj.

\section{REZIME}

\section{MUZEJSKE OBRAZOVNE AKTIVNOSTI NA PRIMERU ARHEOLOGIJE U PTUJU}

Ključne reči: Slovenija, Ptuj-Ormož regionalni muzej, pedagoška i andragoška obrazovna aktivnost, kulturno nasleđe.

Regionalni muzej Ptuj-Ormož je centralni muzej u ptujsko-ormoškoj oblasti. Muzej brine o očuvanju pokretnog kulturnog nasleđa ovog područja od najstarijih vremena do danas. Za posetioce svih uzrasta predstavljamo kulturnu baštinu u vidu muzejskih zbirki, povremenih izložbi i različitim popularizacijskim aktivnostima (publikacije, predavanja, radionice i sl.). Posebnu pažnju obraćamo mladim posetiocima. Kroz različite aktivnosti i edukativne programe možemo ih uz pomoć muzejskih zbirki i predmeta upoznati sa životom u prošlosti. Muzej je obrazovna institucija, ali je takođe i mesto gde se ljubitelji kulturnog nasleđa susreću i druže kako bi predstavili običaje i navike ptujsko-ormoške oblasti domaćoj i stranoj javnosti.

Zahvaljujući izložbi »Prvi razred« u Ptujskom muzeju započeli smo sa inovativnim programom predstavljajući arheološki materijal najmlađoj populaciji. Ovom izložbom smo učinili da se 
deca upoznaju sa kulturnim nasleđem ptujsko-ormoškog područja, a istovremeno, obavestili smo ih o univerzalnom razvoju čovečanstva od najstarijih vremena do današnjih dana. Tokom izložbe pripremili smo lekcije i za učenike različiteih škola. Nakon što su čuli kratko objašnjenje o razvoju keramike u različitim arheološkim vremenskim periodima i videli video film, učenici su oblikovali slične predmete od gline. U narednim godinama nastavili smo projekat »Prvi razred « u Ptujskom muzeju sa različitim pedagoškim i andragoških radionica povezanim sa arheološkim zbirkama ili sa povremenim arheološkim izložbama. $\mathrm{Na}$ ovaj način pokušali smo da predstavimo puls grada $i$ okoline u rimskom dobu i da približimo prošlost svim starosnim grupama, među kojima su čak bile i grupe ljudi sa posebnim potrebama.

Ptujski muzej je takođe i mesto gde se ljubitelji kulturnog nasleđa sastaju i druže u cilju predstavljanja običaja i navika iz ptujsko-ormoškog područja. Neka društva aktivno sarađuju sa Ptujskim muzejom. Tako, Društvo žena i devojaka iz opštine Hajdina učestvuje u pripremi za brojne muzejske manifestacije i samim tim, preuzma brigu o očuvanju starih navika.

U očekivanju buduceg Arheološkiog parka Vicus Fortunae pripremamo različite edukativne radionice koje uključuju poznavanje istorije grada, poznavanje različitih dizajna i tehnika izrade nakita i keramičkih proizvoda, te rimsku kuhinju. Primenom pedagoško-andragoškog obrazovanja u prezentaciji kulturnog nasleđa postigli smo zavidan uspeh o čemu govori nekoliko nacionalnih nagrada koje je Muzej dobio. 